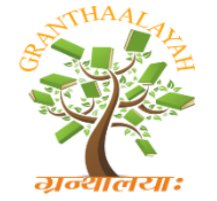

$$
\begin{gathered}
\text { INTERNATIONAL JOURNAL OF RESEARCH - } \\
\text { GRANTHAALAYAH } \\
\text { A knowledge Repository }
\end{gathered}
$$

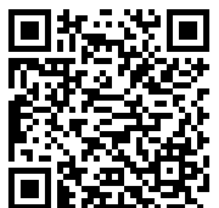

RASM - 17

\title{
IMPACT OF QUARRYING AND CRUSHING ON SOIL QUALITY: A CASE STUDY IN TUMKUR DISTRICT, KARNATAKA
}

\author{
H. Babitha Rani* ${ }^{* 1}$, Shadakshara Swamy ${ }^{2}$, A. L. Bharath ${ }^{1}$, Raghavendra Prasad Havanje \\ Dinakar, ${ }^{1,}$, A. V. Raghu*3 \\ ${ }^{1}$ Department of Civil Engineering, SET, Jain University, India \\ ${ }^{2}$ Department of Geology, Bangalore University, India \\ ${ }^{3}$ Centre for Emerging Technology, SET, Jain University, India \\ DOI: https://doi.org/10.29121/granthaalayah.v5.i4RASM.2017.3363
}

\begin{abstract}
A study was carried out on the impact of quarrying and crushing waste on the quality of soil in Tumkur District. The quarries located in different parts of Tumkur District produces quarry wastes (aggregates), blasted materials (fly rocks), chemicals (explosives used for blasting) and dust (granite powder) generated from activity are spread and settled in the surrounding area. The soil samples were collected both near and away from the quarry and crushing sites. The collected samples were analyzed for various physico-chemical parameters viz temperature, $\mathrm{pH}, \mathrm{EC}$, organic carbon, nitrogen, potassium, phosphorus, zinc, copper, manganese, iron and boron using standard methods. The results revealed the deterioration of soil quality near the quarrying and crushing sites and this can be attributed due to the accumulation of dust. The soil properties are less affected away from the quarry sites.
\end{abstract}

Keywords: Soil Pollution; Stone Quarry and Control Measures.

Cite This Article: H. Babitha Rani, Shadakshara Swamy, A. L. Bharath, Raghavendra Prasad Havanje Dinakar, and A. V. Raghu. (2017). "IMPACT OF QUARRYING AND CRUSHING ON SOIL QUALITY: A CASE STUDY IN TUMKUR DISTRICT, KARNATAKA." International Journal of Research - Granthaalayah, 5(4) RASM, 11-16. https://doi.org/10.29121/granthaalayah.v5.i4RASM.2017.3363.

\section{Introduction}

Among the important components of ecosphere, pedosphere plays a vital role in the sustenance of life. Soil is the cross road for terrestrial communities to link between water, air and mineral core of the earth. The physico-chemical properties of soil and organisms living within determine the kind of crop that can be grown on it [1]. The polluted effluents affect the soil environment and there by the rhizosphere is also disturbed [2]. The soil Cation Exchange Capacity (CEC), porosity and water holding capacity are generally reduced in effluent-polluted soils [3,4] 
[Rani et. al., Vol.5 (Iss.4: RASM), April, 2017]

ICV (Index Copernicus Value) 2015: 71.21

Recent Advances in Sustainable Materials
ISSN- 2350-0530(O), ISSN- 2394-3629(P)

IF: 4.321 (CosmosImpactFactor), 2.532 (I2OR)

InfoBase Index IIBI Factor 3.86

reported that erosion, sedimentation process, translocation of waste gases, and leachates changed the soil around the landfills and the soil composition of the adjacent area in a Berlin landfill.

\section{Materials and Methods}

\subsection{Study Area}

The study area geographically lies between $\mathrm{N} 12^{\circ} 45^{\prime}$ to $14^{\circ} 20^{\prime} \mathrm{E}$ and $76^{\circ} 20^{\prime}$ to $77^{\circ} 31^{\prime}$. It is well connected with all the Taluk head quarters and neighboring districts.

Tumkur belongs to the group of District called maiden (plains) District and is situated in the east central part of Southern Karnataka. The district covers an area of $10535 \mathrm{~km}^{2}$. Peninsular gneiss, enclaves of sargur complex are exposed to the South of Turuvekere and Kunigal and the rock type comprises of garnet-sillimanite bearing quartzite, ultramafic rocks and amphibolites. This study was conducted primarily in the quarries and crushing sites in and around Pemmanahalli, Danapura, Nandihalli, Oblapura, and Pandithanahalli, Sathyamangala industrial area, Somadevanahalli, Yelladadlur and Maddakanahalli of Tumkur District. Solid wastes generated are disposed off in a temporary dumpsite with its leachet affecting the immediate soil quality. These leachet in combination with the plant effluents are also affecting the surrounding agricultural lands in all most all quarrying and crushing units.

\subsection{Materials}

The soil samples at a depth of $15 \mathrm{~cm}$ were collected cross sectionally along wind direction within and around the vicinity of the quarrying and crushing sites in Tumkur district, to study the impact. Soil samples were collected maintaining a distance of about 50, 100, 150 and $400 \mathrm{~m}$ from the quarrying and crushing areas. Soil samples from quarry pit, overburden and top soil near the quarry and from the agricultural lands were collected for analysis. Apart from the collection of soil an observation checklist was also employed to make visual and qualitative assessment of farming activities in the area.

\subsection{Methods}

Soil samples were analyzed by using various chemical characteristics. The physical parameters determined were $p \mathrm{H}$ value and conductivity. The $p \mathrm{H}$ value was measured using a standard $p \mathrm{H}$ meter model 308 made by SYSTRONICS and the conductivity measurement was made by a standard conductivity meter model 308 supplied by systronics. In both the cases, $20 \mathrm{~g}$ of soil samples were weighed and suspended in $50 \mathrm{ml}$ of distilled water and stirred before introducing probe.

Chemical parameters determined are organic carbon, available nitrogen, available phosphorous and available potassium. Metals such as $\mathrm{Zn}, \mathrm{Cu}, \mathrm{Mn}, \mathrm{Fe}$ as well as boron were determined.

Organic carbon was estimated by wet digestion method, nitrogen by total (Kjedahl) nitrogen method and phosphorus determination was done spectrophotmetrically using molybdovanadate method according to AOAC methods of analysis. Phosphate was determined 
[Rani et. al., Vol.5 (Iss.4: RASM), April, 2017]

ICV (Index Copernicus Value) 2015: 71.21

Recent Advances in Sustainable Materials
ISSN- 2350-0530(O), ISSN- 2394-3629(P)

IF : 4.321 (CosmosImpactFactor), 2.532 (I2OR) InfoBase Index IBI Factor 3.86

spectrophotmetrically using the persulphate digestion methods [5], and nitrate was determined spectrophotometrically using phenol disulphonic acid method [6]. The analysis of soil samples for all metals was done using Atomic absorption spectrophotometer (AAS) model 932 plus supplied by GBC scientific equipment Pvt. Ltd. In each case, soil samples were subjected to pretreatment which include air drying, sieving and acid digestion before analysis.

Table 1: Analytical data of soil with fertility rating (ICAR, 1997)

\begin{tabular}{|c|c|c|c|c|c|c|}
\hline \multirow[t]{2}{*}{ Soil parameters } & \multicolumn{3}{|c|}{ Statistical values } & \multicolumn{3}{|c|}{ Rating } \\
\hline & Average & Maximum & Minimum & Low & Medium & High \\
\hline$p \mathbf{H}($ Units $)$ & 6.4 & 8.8 & 5.1 & $<6.3$ & $6.3-8.3$ & $>8.3$ \\
\hline Electrical & 114.162 & 418 & 30 & $>100$ & - & - \\
\hline $\begin{array}{c}\text { Conductance }(\text { mhos } / \mathrm{cm}) \\
\text { Organic Carbon }(\%)\end{array}$ & 0.54 & 1.6 & 0.1 & $<0.5$ & $0.5-0.75$ & $>0.75$ \\
\hline $\begin{array}{c}\text { Available Phosphorus } \\
\text { (Kg/acre) }\end{array}$ & 13.94 & 72.9 & 0.6 & $<9$ & $9-22$ & $>22$ \\
\hline $\begin{array}{c}\text { Available Potassium } \\
\text { (Kg/ha) }\end{array}$ & 72.26 & 160.2 & 8.5 & $<50$ & $50-120$ & $>120$ \\
\hline $\begin{array}{c}\text { Available Nitrogen } \\
\text { (Kg/ha) }\end{array}$ & 48.60 & 113 & 8.1 & $<112$ & $112-224$ & $>224$ \\
\hline Zinc (mg/l) & 1.53 & 4.2 & 0.5 & $<1.0$ & - & - \\
\hline Copper (mg/L) & 4.03 & 16 & 0.4 & $<0.40$ & - & - \\
\hline Manganese (mg/L) & 5.17 & 24.9 & 1.1 & $<2.00$ & - & - \\
\hline Iron (mg/L) & 6.53 & 15.9 & 0.9 & $<4.50$ & & \\
\hline Boron(mg/L) & 0.40 & 0.92 & 0 & $<0.50$ & - & - \\
\hline
\end{tabular}

\section{Results and Discussions}

\section{Impact of Quarrying and Crushing Sites on Soil Quality}

The soil color is generally red with brownish tinge. Soil samples invariably contain stones and rock powder. The quarry wastes (aggregates), blasted materials (fly rocks), chemicals (explosives used for blasting) and dust (granite powder) generated from the activity are spread and settled in the surrounding areas of the quarry sites.

The highest $p \mathrm{H}$ value measured in the soils of the study area is around 5.1, whereas at a distance of 50 meters in the same region the $p \mathrm{H}$ value is 8.6. The lowest $\mathrm{pH}$ value measured in the soils of the study area is around 5.1 and it is from the quarries of Nandihalli, Pandithnahalli and Kowthmaranahalli. The variation in $p \mathrm{H}$ level is attributed to the semiarid nature of the terrain and to the different types of explosives employed in the quarry sites. However significant contribution from the leachate emanating from the quarry dumpsites to the variation in $p \mathrm{H}$ level cannot be neglected. $\mathrm{H}^{+}$and $\mathrm{OH}^{-}$ions liberated from the residues also contribute significant in the variation in $p \mathrm{H}$ levels. 
[Rani et. al., Vol.5 (Iss.4: RASM), April, 2017]

ICV (Index Copernicus Value) 2015: 71.21

Recent Advances in Sustainable Materials
ISSN- 2350-0530(O), ISSN- 2394-3629(P)

IF: 4.321 (CosmosImpactFactor), 2.532 (I2OR)

InfoBase Index IBI Factor 3.86

The EC value in the soil samples of the study area ranges from $30 \mu \mathrm{ohms} / \mathrm{cm}$ to $418 \mu \mathrm{ohms} / \mathrm{cm}$. The lowest EC value is observed near Maidala and Pandithnahalli at a $300 \mathrm{~m}$ distance is $30 \mu$ $\mathrm{ohms} / \mathrm{cm}$. Higher EC values recorded in the soil samples is $418 \mu \mathrm{ohms} / \mathrm{cm}$ at $400 \mathrm{~m}$ distance from the quarry in Bukkapatna village.

The variation in EC can be attributed to the leachate explosive materials that got accumulated on the soil surface due to quarry activity. The soil OC in the study area ranges between $0.1 \%$ to $1.64 \%$ with a mean value of $0.71 \%$. In all the 32 quarry locations, the soil samples show increasing organic carbon with increase distance.

Lowest organic carbon value in the soil samples of the study area is around $0.1 \%$ at the quarry present in Taverekere. The highest organic carbon value observed at Pemmanahalli at a distance of 250 meters away from the quarry is $1.6 \%$. Low organic carbon content may be attributed to the addition of quarry dust near the crushing sites by way of aerial deposition. Dust accumulation due to quarrying and crushing activity gradually decreases with the distance. The highest available nitrogen is recorded at Ranganahalli $(113 \mathrm{Kg} / \mathrm{acre})$ at a distance of 350 meters away from the quarry. Lowest available nitrogen value observed in the study area is around 8.1 $\mathrm{Kg} / \mathrm{acre}$ is at Mudegerekaval at a distance of 50 meters away from the quarry. The nitrogen was low near the quarry area due to low organic carbon and significant accumulation of dust in the fields. Nitrogen and ammonia are produced in the soil by the action of microorganisms on the soil organic matter and this may be the reason for increase in available nitrogen away from the quarry sites.

The highest value of available phosphorous $(71.1 \mathrm{Kg} / \mathrm{acre})$ was recorded at Maidala quarry is at a distance of 300meter. Lowest available phosphorous value observed in the study area is around $0.9 \mathrm{~kg} / \mathrm{acre}$ at a distance of 50 meter away from the quarry is at Kanthivadaeanhalli. The high content of phosphorus occurs mainly as calcium phosphate which, in turn is partially derived from rocks being weathered. The low content of phosphorous near the quarry sites is due to low organic carbon and significant accumulation of dust in the agricultural fields.

Lowest available potassium value observed in the study area is around $12 \mathrm{Kg}$ /acre at a distance of 50 meters is at Siddapura quarry. The highest available potassium value is observed at Maidala quarry at a distance of 300 meters $(160 \mathrm{Kg} / \mathrm{acre})$. The high concentration of available potassium may be due to the presence of primary minerals such as micas and potassium feldspar. Because of hydration, mobile elements potassium $(\mathrm{K})$ is leached out during the chemical reaction and carried away as dissolved salt. Lower values of available potassium can be attributed to the addition of quarry dust near the quarry and crushing sites.

$\mathrm{Zn}$ ranges between $0.5 \mathrm{mg} / \mathrm{l}$ with an average of $1.5 \mathrm{mg} / \mathrm{L}$. The high content of zinc may be attributed to the deposition of accumulated dust. In the absence of any major metal smelting operations, the primary source of zinc in urban street is probably the attrition of vehicle tire rubber [7]. Sewage sludge soils show higher concentration of zinc [8] and addition of fertilizers to the soil such as nitrate, phosphate and ammonium nitrate increase the concentration of zinc [9]. The highest copper value observed at Pemmanahalli and Somadevanahalli is at a distance of 50 meters from the quarries $(9.1 \mu \mathrm{g} / \mathrm{g})$. Lowest value in the study area is around $1 \mu \mathrm{g} / \mathrm{g}$ at a distance of 50 meter in the Bukkapatna quarry. 
The lowest boron value measured $(0.12 \mu \mathrm{g} / \mathrm{g})$ in the study area is from the quarries at Somadevanahallli and Tippanahalli at a distance of 50 meters. The highest boron value observed is at Bukkapatna at a distance of 50 meter is $0.76 \mu \mathrm{g} / \mathrm{g}$.

Variation in the concentration of boron in soil is mainly due to its leaching from strongly acidic sandy soils which decompose during the formation of soil. Boron occurs as borate and borosilicate which are micronutrients.

The lowest iron content observed in the study area $(0.93 \mu \mathrm{g} / \mathrm{g})$ is at Chikkagundanahalli quarry at a distance of 50 meters. The highest Iron value observed is at Kardigrama at a distance of 250 meters from the quarry is $16 \mu \mathrm{g} / \mathrm{g}$. A marked change of iron concentration is observed in the soils of Uttar Pradesh, which has been reported as a derivative from industrial activity, agriculture and municipal sewage [10].

The high content of manganese observed at a distance of 400 meters from Somadevanahlli quarry is $24.9 \mu \mathrm{g} / \mathrm{g}$. The lowest manganese content observed is at Egihalli and Oblapura at a distance 50 meters is $1.1 \mu \mathrm{g} / \mathrm{g}$.

\section{Conclusions}

The present study indicates that a quarrying/crushing activity is causing degradation of soil fertility characteristics. The spent explosives and the crushed rock debris dumped in the vicinity are affecting the organic carbon and nitrogen content in the soils of nearby agricultural fields. During raining the runoff from the dumps and waste materials results in the degradation of soil fertility of the surrounding agricultural fields. The NPK values show a steady increase with increasing distance from the quarrying and crushing operations. The substantial amount of coarse and fine sand is getting added to the soil. Gravel extraction may often leave behind large water filled pits. These pits, if managed correctly, may become valuable wildlife habitat for wetland and water creatures.

\section{Acknowledgements}

The authors would like to thank P.V. S. Aravind and V. Avinash for providing technical support on the experimental part of this work.

\section{References}

[1] SAHAI, R., SHUKLA, N., JABEEN, S. and SAXENA, P.K. Environment pollute.37, 1985, 245.

[2] SEN AMARTYA, K. Economic Ecology and public action Personal communication, 23, 1998,.22.

[3] GOLDTICH, S.S. A study on rock weathering. Jour. Geology, V. 46, 1938, 17.

[4] REKHA GHOSH AND SAXENA, N.C. Small scale mining environmental impacts, 67, 1995, 95.

[5] APHA. Standard methods for the examination of water and waste water, American Public Health Association; 16th Edition, Newyork, USA1992.

[6] TARA, J.M. Phenoldisulphonic acid method of determining nitrate in water. The Journal of Analytical Chemistry. 22, 1950, 1020-1022. 
[Rani et. al., Vol.5 (Iss.4: RASM), April, 2017]

ICV (Index Copernicus Value) 2015: 71.21

Recent Advances in Sustainable Materials
ISSN- 2350-0530(O), ISSN- 2394-3629(P)

IF : 4.321 (CosmosImpactFactor), 2.532 (I2OR)

InfoBase Index IBI Factor 3.86

[7] HEWITT, C. N and RASHED, M.B. A BUDGET FOR SELECTED POLLUTANTS EMITTED FROM A MAJOR RURAL HIGHWAY, Sci. Total Environ. 68, 1979, 165.

[8] SANDERS, J.R., McGRATH, S.P and ADAMS, T.M. Zinc, Copper and Nickel concentrations in soil extracts and crops grown on four soils treated with metal loaded sewage sludges. Environ. Pollut., 44, 1989, 193-210.

[9] JOHAN, B. and ELIEL, S. Vegetation established on a deposit of Zinc mine wastes. Environ. Pollut., 56, 1965, 129-144.

[10] ISRALI, A.W., ALENABI and NAGVI, S.Q. (1990). Heavy metal pollution studies in western Uttar Pradesh. Pollut. Res. 9, 1990, 57-61.

*Corresponding author.

E-mail address: babithahemah@yahoo.com/gsraghu2003@yahoo.co.in 